\title{
Blue remembered hills
}

\author{
Fiona Godlee editor in chief
}

The BMJ

We've heard a lot about intergenerational strife since the United Kingdom voted to leave the European Union in last month's referendum. Younger voters, who overwhelmingly voted to remain, feel betrayed. Older voters, with less of a lifetime to lose, are accused of harbouring unrealistic nostalgia for a Britain that never existed. Something similar afflicts the dispute over the junior doctor contract, which reached another milestone this week as juniors voted to reject the latest offer (doi:10.1136/bmj. i3749). Although many senior colleagues are vocal in their support, mutterings from some suggest that the juniors don't know what hard work is.

Harold Ellis, who trained in the 1950s, is of this view (doi:10. 1136/bmj.i3662). But he also says that juniors now have a lot to complain about: "We had more responsibility and much longer hours ... They aren't getting properly trained or the experience they need," he says.

Others who trained in the intervening decades seem to agree. Shorter hours have brought some gains: more sleep, at least, and perhaps improved patient safety. But they have short changed doctors of all grades in other ways, with losses in training, support, camaraderie, and job satisfaction. The tipping point seems to have been in the 2000s. Tom Fardon was a junior doctor when the European Working Time Directive came into force. "Ward work changed from 'firms' [led by consultants] to ward based teams. Many of us mourn that loss because the start of my training was an apprenticeship, learning from those above you, and inspired by the consultant who led the firm. That's gone." Current trainee Deborah Kirkham confirms this: "Our lives are easier in some ways, although we don't have the same support as colleagues had in the past, and that makes the difficult things more difficult to deal with."

Given these potent echoes from a golden age, can a post-Brexit UK dispense with the Working Time Directive? Not easily, says Andrew Goddard (doi:10.1136/bmj.i3702). The directive is enshrined in UK law, and the unions, including the BMA, would resist legislative change.

However, two newer additions to the regulations could be ditched, he says, allowing more flexible on-call working. Ultimately, though, it has always been in our power to protect the medical firm structure, maintain high quality training, improve patient safety, and keep reasonable working hours. Employing many more doctors would achieve this, Goddard says, whether they have been trained in the UK or abroad. This would need more funding for the NHS, of course. Sadly, in light of the Brexit decision and despite increasingly impassioned calls, including from the BMA's chair of council (http://blogs. bmj.com/bmj/2016/07/05/mark-porter-the-nhs-and-a-350m-lie/ ), this doesn't seem likely any time soon. 